the probable maximum, the Leonids were again very scarce. It therefore seems unlikely that there was any extraordinary display at that epoch. British observers generally experienced cloudy skies at that time, so that a definite statement cannot be made until reports from more favoured localities come in. Dr. S. C. Blacktin, 20 Denton Avenue, Roundhay, Leods 8, has sent a report of a meteor seen at Leeds at 5.30 p.m. on November 16. This could not have been a Leonid, since the radiant at that time was $13^{\circ}$ below the north-north-west horizon.

\section{Recent Shower of Meteors}

A wireless message from Mohd. A. R. Khan, of Begumpet, Deccan, India, presumably sent on November 22, reads as follows: "Splendid meteoric shower last night. Gamma Monocerotis radiant." Assuming the radiant to have been exactly at $\gamma$ Monocerotis (R.A. $114 \cdot 5^{\circ} ; \delta-9 \cdot 4^{\circ}$ ), and taking the date as Greenwich midnight of November 21 (November 22, Oh. U.T.), Mr. A. King has computed the following parabolic orbit : $\iota, 115 \cdot 0^{\circ} ; \pi, 135 \cdot 4^{\circ} ; \Omega, 58 \cdot 8^{\circ}$; $q, 0 \cdot 608$. The recently published "Index to Southern Meteor Showers" by Mr. R. A. McIntosh, of Auckland, N.Z., gives two radiants at $114 \frac{1}{2}^{\circ}-9^{\circ}$, November 15-16. Possibly Mr. Khan's shower represents a continuation of this stream, but more cannot be said until definitive details come to hand.

\section{Announcements}

THE Symons Gold Medal for 1936 of the Royal Meteorological Society has been awarded to Prof. Wilhelm Schmidt, director of the Central Institution for Meteorology and Geodynamies, Vienna. The medal is awarded biennially for distinguished work in connexion with meteorological science and will be presented at the annual general meeting of the Society on January 15, 1936.

The Thomas Young Oration of the Physical Society will be given by Prof. Charles Fabry of the Institut d'Optique, Paris, on December 6 at 5 p.m. at the Imperial College of Science and Technology, South Kensington, S.W.7. The title of the lecture will be "Vision in Optical Instruments".

The Right Hon. Lord Rutherford will open the new Research Laboratory of the London Midland and Scottish Railway Company at Derby on Tuesday, December 10 at 1.50 p.m.

The opening of the next annual meeting of the Institution of Naval Architects will fall on April 1, 1936. A joint summer meeting will be held in the United States on September 14-19, 1936, at the invitation of the American Society of Naval Architects and Marine Engineers. Other British and foreign institutions will take part.

The tenth Triennial Congress of the International Society of Surgery, of which 1,200 surgeons from 42 different countries are members, will be held at Cairo on December 30-January 4, under the presidency of
Dr. Jan Schoemaker of The Hague. Further information can be obtained from the general secretary, Dr. L. Mayer, 72 rue de la Loi, Brussels.

ON the occasion of the seventy-fifth anniversary of its foundation, the Dr. C. Schleussner Company of Frankfort-on-Main offers a prize of 2,000 gold marks for the best scientific work on rontgenology. The president of the German Rontgen Society, in conjunction with the Dr. C. Schleussner Company, will decide the award. Purely technical and statistical works as well as those already published are excluded from the competition.

The sixth assembly of the Spanish League of Mental Hygiene will be held in Madrid on December 2-6, when the following subjects will be discussed: suicide in Spain in its psychological and social aspects, the organisation of psychiatric assistance in families, and the intervention of the psychiatrist in tribunals for minors. The fee of five pesetas should be sent to the treasurer, Dr. A. Garma Cisne, 10, Madrid, from whom further information can be obtained.

Erratum.--In the last line of the letter "Records of Fatálities from Falling Meteorites", by Mohd. A. R. Khan, in NATuRE of October 12, p. 607, for "Kawagam" read "Kawagaon".

Applications are invited for the following appointments, on or before the dates mentioned :

A principal of the Rochdale Municipal Technical School-The Seoretary, Education Office, Townhead, Rochdale (Dec. 5).

The following appointments in the University of Cambridge : a University lecturer and a University demonstrator in biochemistry (Sir F. G. Hopkins, Dec. 7) ; two University demonstrators in chemistry (Dr. R. G. W. Norrish); University demonstrator in zoology (Prof. J. Stanley Gardiner, Dec. 31).

A principal of the North-Western Polytechnic, Prince of Wales Road, Kentish Town, London, N.W.5-The Clerk to the Governors (Dec. 12).

An assistant (Grade III) in metallurgy and a junior scientific officer in the Royal Aircraft Estab. lishment, South Farnborough, Hants--The Chief Superintendent (Dec. 13).

A lecturer in organic chemistry in the Birmingham Central Technical College--The Principal (Dec. 14).

A lecturer in chemistry in the University of Capetown-The Secretary, Office of the High Commissioner for South Africa, Trafalgar Square, London (Dec. 31).

A professor of chemistry in the University of Otago-The High Commissioner for New Zealand, 415 Strand, London, W.C.2 (Jan. 6).

A lecturer (woman) in biology in the Darlington Training College-The Principal.

A lecturer in electrical engineering in the Burmah Oil Company's College of Mining and Engineering, University of Rangoon-The Secretary, Universities Bureau of the British Empire, 88A Gower Street, W.C.1. 